\title{
Article
}

\section{Alcohol-assisted synthesis of high-silica zeolites in the absence of organic structure-directing agents}

\author{
Huimin Luan a, Chi Lei a, Ye Ma a, Qinming Wu a,*, Longfeng Zhu ${ }^{\text {b }}$, Hao Xu ${ }^{\text {a }}$, Shichao Han a, \\ Qiuyan Zhu a, Xiaolong Liu ${ }^{c, \#, ~ X i a n g j u ~ M e n g ~ a, ~ F e n g-S h o u ~ X i a o ~}{ }^{\mathrm{a}, \$}$ \\ a Key Laboratory of Applied Chemistry of Zhejiang Province, Department of Chemistry, Zhejiang University, Hangzhou 310028, Zhejiang, China \\ b College of Biological, Chemical Science and Engineering, Jiaxing University, Jiaxing 314001, Zhejiang, China \\ c School of Material, Sun Yat-Sen University, Guangzhou 510006, Guangdong, China
}

\section{A R T I C L E I N F O}

\section{Article history:}

Received 8 May 2020

Accepted 25 June 2020

Available online 5 September 2020

\section{Keywords:}

Zeolite

High silica

Seed directing

Alcohol filling

Catalytic performance

\begin{abstract}
A B S T R A C T
In this work, we show for the first time that high-silica zeolites (MFI, TON, MTT, and *MRE) could be synthesized from a combined strategy of both zeolite seeding and alcohol filling in the absence of organic structure-directing agents (OSDAs). High-silica ZSM-5 zeolites with $\mathrm{Si} / \mathrm{Al}$ ratios ranging from 38 to 240 (TF-Al-ZSM-5) could be synthesized via this route. The key to the success of this technique was the employment of an aluminosilicate precursor with a fully 4-coordinated aluminum species as the initial source, wherein the rearrangement and condensation of the silicate species, rather than the aluminate species, occurred during zeolite crystallization. In addition, heteroatoms, such as $\mathrm{Fe}$ and $\mathrm{B}$, could be incorporated into the zeolite frameworks. Catalytic tests for the methanol-to-propylene (MTP) reaction exhibited good catalytic performance for TF-Al-ZSM-5, which was comparable to that of the aluminosilicate ZSM-5 zeolite synthesized with OSDAs. Hence, this method offers viable opportunities for the industrial production and catalytic application of high-silica zeolites in the future.
\end{abstract}

(C) 2021, Dalian Institute of Chemical Physics, Chinese Academy of Sciences. Published by Elsevier B.V. All rights reserved.

\section{Introduction}

Zeolites, particularly high-silica zeolites, have been extensively applied in the field of catalysis for decades owing to their excellent thermal and hydrothermal stabilities, large micropore volumes, high surface areas, and uniform microporous channels [1-27]. For example, high-silica aluminosilicate ZSM-5 zeolite is widely used in the methanol-to-propylene (MTP) reaction [22-24], and high-silica aluminosilicate ZSM-48 zeolite is an efficient catalyst for the hydroisomerization of $n$-alkanes
[24-27]. Generally, high-silica zeolites are synthesized in the presence of organic structure-directing agents (OSDAs), such as quaternary ammonium cations and amines, which direct the assembly pathway and ultimately fill the zeolite micropores [8-27]. The employment of these OSDAs not only increases the cost but also produces a large amount of polluted water. In addition, the zeolite framework sometimes would deteriorate during the removal of organic templates due to high temperature calcination.

In the past years, great efforts have been made to develop

\footnotetext{
* Corresponding author. Tel/Fax: +86-571-8273698; E-mail: qinmingwu@zju.edu.cn

\# Corresponding author. Tel/Fax: +86-20-83642214; E-mail: liuxlong9@mail.sysu.edu.cn

\$Corresponding author. Tel/Fax: +86-571-8273698; E-mail: fsxiao@zju.edu.cn

This work was supported by the National Key Research and Development Program of China (2017YFB0702803) and the National Natural Science Foundation of China $(21720102001,91634201,21703203,21802053)$.

DOI: 10.1016/S1872-2067(20)63677-4 | http://www.sciencedirect.com/science/journal/18722067 | Chin. J. Catal., Vol. 42, No. 4, April 2021
} 
novel routes for the synthesis of zeolites, such as avoiding the use of organic templates, including the introduction of a seed solution into the starting gel, adjusting the initial gel, and adding zeolite seeds into the starting gels [28-34]. Among such approaches, the addition of zeolite seeds into the starting gels, which is called seed-directed synthesis, is an efficient method for successful organotemplate-free synthesis of zeolites [30-34]. Despite the considerable progress in seed-directed synthesis of zeolites in the past decade, the zeolite products obtained are always Al-rich [30-34].

Recently, our group has reported that pure silica zeolites could be successfully synthesized using a combined strategy of both zeolite seeding and alcohol filling in the absence of OSDAs, which can be regarded as a breakthrough in the synthesis of pure silica zeolites [35]. However, from the viewpoint of catalytic applications, high-silica zeolites, such as aluminosilicate and ferrosilicate zeolites, are more attractive than pure silica zeolites. Currently, there is still a great challenge in synthesizing high-silica (Si-rich) zeolites in the absence of OSDAs using an aluminosilicate precursor as the starting source.

In this work, we report a successful organotemplate-free synthesis of high-silica zeolites (TF-zeolites) in the presence of zeolite seeds and ethanol. When aluminosilicate precursors with fully 4-coordinated aluminum species were used as the starting sources, TF-Al-ZSM-5 zeolites with $\mathrm{Si} / \mathrm{Al}$ ratios ranging from 38 to 240 were successfully synthesized. Furthermore, organotemplate-free synthesis was extended to the preparation of TF-TON, TF-MTT, and TF-*MRE; heteroatoms such as Fe and B could also be incorporated into the zeolite framework, thus forming ferrosilicate and borosilicate zeolites, such as TF-Fe-ZSM-5 and TF-B-ZSM-5, respectively.

\section{Experimental}

\subsection{Materials}

Sodium aluminate $\left(\mathrm{NaAlO}_{2}, 36.6 \% \mathrm{Na}_{2} \mathrm{O}\right.$ and $43.3 \% \mathrm{Al}_{2} \mathrm{O}_{3}$, Sinopharm Chemical Reagent Co., Ltd.), sodium hydroxide (NaOH, AR, 96\%, Sinopharm Chemical Reagent Co., Ltd.), sodium metasilicate nonahydrate $\left(\mathrm{Na}_{2} \mathrm{SiO}_{3} \cdot 9 \mathrm{H}_{2} \mathrm{O}, 98 \%\right.$, Aladdin Chemistry Co., Ltd.), sodium borate tetrahydrate $\left(\mathrm{NaBO}_{2} \cdot 4 \mathrm{H}_{2} \mathrm{O}\right.$, AR, 99\%, Sinopharm Chemical Reagent Co., Ltd.), iron nitrate nonahydrate $\left(\mathrm{Fe}\left(\mathrm{NO}_{3}\right)_{3} \cdot 9 \mathrm{H}_{2} \mathrm{O}, \mathrm{AR}, 98.5 \%\right.$, Aladdin Chemistry Co., Ltd.), ethanol (99.8\%, Sinopharm Chemical Reagent Co., Ltd.), methanol (98\%, Sinopharm Chemical Reagent Co., Ltd.), colloidal silica (LUDOX HS-40, $40 \mathrm{wt} \% \mathrm{SiO}_{2}$ in $\mathrm{H}_{2} \mathrm{O}$, Sigma-Aldrich Reagent Co., Ltd.), tetrapropylammonium hydroxide (TPAOH, $40 \mathrm{wt} \%$ in water, Kente Catalysts Co., Ltd.), aluminosilicate ZSM-5 zeolite $(\mathrm{Si} / \mathrm{Al}=100$, Nankai University Catalyst Co., Ltd.), and silicalite-1 zeolite (Nankai University Catalyst Co., Ltd.) were employed without further purification. The deionized water was produced inhouse.

\subsection{Synthesis}

\subsubsection{Precursor synthesis}

As a typical example, the aluminosilicate precursor was prepared from $\mathrm{NaAlO}_{2}$ and colloidal silica. Initially, a certain amount of $\mathrm{NaAlO}_{2}$ was dissolved in $3.0 \mathrm{~g}$ of $\mathrm{H}_{2} \mathrm{O}$, followed by the addition of the $\mathrm{NaAlO}_{2}$ solution to $50 \mathrm{~g}$ of colloidal silica (40 wt $\% \mathrm{SiO}_{2}$ in water) under stirring conditions. After stirring for another $2 \mathrm{~h}$, the mixture was heated in an oven at $150{ }^{\circ} \mathrm{C}$ for 12 $\mathrm{h}$ to evaporate the water. Finally, the aluminosilicate precursor was obtained. The change in $\mathrm{Si} / \mathrm{Al}$ ratios of the aluminosilicate precursors could be adjusted using the amount of $\mathrm{NaAlO}_{2}$ added into the colloidal silica.

Similarly, borosilicate and ferrosilicate precursors were also prepared from the colloidal silica mixed with a $\mathrm{NaBO}_{2}$ solution or $\mathrm{Fe}\left(\mathrm{NO}_{3}\right)_{3}$ solution, respectively, and the details are given in the Supplementary Information.

\subsubsection{Zeolite synthesis}

As a typical example, the organotemplate-free synthesis of high-silica ZSM-5 was performed using the aluminosilicate precursor in the presence of ZSM-5 seeds and ethanol. Initially, $0.30 \mathrm{~g}$ of $\mathrm{Na}_{2} \mathrm{SiO}_{3} \cdot 9 \mathrm{H}_{2} \mathrm{O}, 1.60 \mathrm{~g}$ of the aluminosilicate precursor $(\mathrm{Si} / \mathrm{Al}=80)$, and $0.16 \mathrm{~g}$ of ZSM-5 seeds $(\mathrm{Si} / \mathrm{Al}=100)$ were mixed, followed by the addition of $1.9 \mathrm{~g}$ of ethanol. After heating at $180{ }^{\circ} \mathrm{C}$ for $48 \mathrm{~h}$ in an autoclave, the product was finally crystallized, and it was designated as TF-Al-ZSM-5. The yield of the TF-Al-ZSM-5 zeolite was approximately 93\%.

Similarly, the organotemplate-free syntheses of MFI containing B or Fe species in the framework were performed using borosilicate and ferrosilicate precursors, giving zeolite products designated as TF-B-ZSM-5 and TF-Fe-ZSM-5, respectively. In addition, the organotemplate-free syntheses of high-silica TON, MTT, and *MRE zeolites were also performed. The details are given in the Supplementary Information.

In a typical run of the synthesis of conventional aluminosilicate MFI zeolites, $0.013 \mathrm{~g}$ of $\mathrm{NaAlO}_{2}$ and $8.0 \mathrm{ml}$ of TPAOH (40 wt\%) were added to $4.2 \mathrm{~g}$ of $\mathrm{H}_{2} \mathrm{O}$, resulting in a clear solution. After the addition of $2.5 \mathrm{~g}$ of colloidal silica ( $40 \mathrm{wt} \% \mathrm{SiO}_{2}$ in water), the mixture was formed. After stirring for $4 \mathrm{~h}$, the mixture was transferred into an autoclave and heated at $180{ }^{\circ} \mathrm{C}$ for $24 \mathrm{~h}$. The resulting product was fully crystallized, and it was designated as C-Al-ZSM-5.

\subsection{Characterization}

X-ray powder diffraction (XRD) patterns were measured using a Rigaku Ultimate VI X-ray diffractometer ( $40 \mathrm{kV}, 40 \mathrm{~mA})$ with $\mathrm{Cu} K_{\alpha}(\lambda=1.5406 \AA)$ radiation. Scanning electron microscopy (SEM) experiments were performed using Hitachi SU-1510 electron microscopes. The $\mathrm{N}_{2}$ sorption isotherms at the temperature of liquid nitrogen were measured using a Micromeritics ASAP 2020M and Tristar system. The thermogravimetry-differential thermal analysis (TG-DTA) experiments were carried out using a Perkin-Elmer TGA 7 unit in air at a heating rate of $10{ }^{\circ} \mathrm{C} / \mathrm{min}$ with the temperature ranging from room temperature to $800{ }^{\circ} \mathrm{C}$. The sample composition was determined using inductively coupled plasma (ICP) with a Perkin-Elmer 3300DV emission spectrometer. Moreover, ${ }^{13} \mathrm{C},{ }^{11} \mathrm{~B}$, ${ }^{29} \mathrm{Si}$, and ${ }^{27} \mathrm{Al}$ MAS NMR spectra were recorded using a Bruker AVANCEШ 500WB spectrometer. Diffuse reflectance ultravio- 
let-visible (UV-Vis) spectra were measured using a Perkin-Elmer Lambda 20 spectrometer, and $\mathrm{BaSO}_{4}$ was the internal standard. X-ray photoelectron spectroscopy (XPS) experiments were performed using Kratos AXIS Supra and the binding energy (BE) values were calibrated using the $\mathrm{C} 1 \mathrm{~s}$ peak at $284.8 \mathrm{eV}$. The acidity of the catalysts was measured using the temperature-programmed-desorption of ammonia ( $\mathrm{NH}_{3}$-TPD). The catalyst sample $(100 \mathrm{mg})$ was pretreated at $550{ }^{\circ} \mathrm{C}$ in a $\mathrm{He}$ flow (30 $\mathrm{mL} / \mathrm{min}$ ) for $30 \mathrm{~min}$, followed by the adsorption of $\mathrm{NH}_{3}$ at $100{ }^{\circ} \mathrm{C}$ for $30 \mathrm{~min}$. After saturation, the sample was purged using the He flow for $1 \mathrm{~h}$ to remove the physically adsorbed ammonia from the sample. Then, desorption of $\mathrm{NH}_{3}$ was carried out from 100 to $650^{\circ} \mathrm{C}$ with a heating rate of $10^{\circ} \mathrm{C} / \mathrm{min}$. The amount of $\mathrm{NH}_{3}$ desorbed from the sample was detected by a thermal conductivity detector.

\subsection{Catalytic tests}

The MTP reaction was carried out with a fixed-bed tubular steel reactor with an inner diameter of $8 \mathrm{~mm}$ and a length of 30 $\mathrm{cm}$ under atmospheric pressure. After $0.50 \mathrm{~g}$ of the catalyst (20-40 mesh) was loaded in the middle of the tubular steel between two layers of quartz wool, it was pre-treated in flowing nitrogen at $500{ }^{\circ} \mathrm{C}$ for $2 \mathrm{~h}$ and cooled down to a reaction temperature of $480{ }^{\circ} \mathrm{C}$. Methanol was injected into the catalyst bed using a pump with a weight hourly space velocity (WHSV) of $1.0 \mathrm{~h}^{-1}$. The products from the reactor were analyzed on-line using an Agilent 6890N gas chromatograph equipped with an FID detector and a $\mathrm{PLOTAl}_{2} \mathrm{O}_{3}$ capillary column.

\section{Results and discussion}

Figure 1 shows the schematic representation of the organotemplate-free synthesis of high-silica zeolites including the preparation of the aluminosilicate precursor; the grinding of the precursor with $\mathrm{Na}_{2} \mathrm{SiO}_{3} \cdot 9 \mathrm{H}_{2} \mathrm{O}$, ethanol, and zeolite seeds; and the heating at an appropriate temperature and time for the crystallization. As a typical example, the organotemplate-free synthesis of a high-silica ZSM-5 zeolite with a Si/Al ratio of 80 in the starting solid mixture (TF-Al-ZSM-5-80) was investigated.

Figure 2 shows the XRD pattern, SEM image, nitrogen sorption isotherms, MAS NMR spectra, and TG curve of

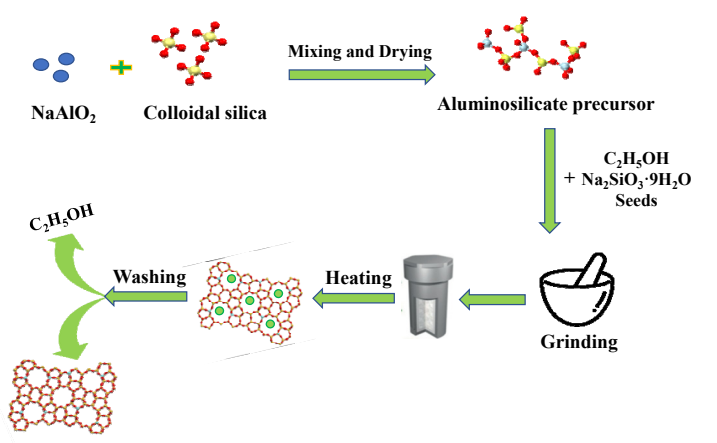

Fig. 1. Schematic representation of the synthesis of high-silica zeolites.
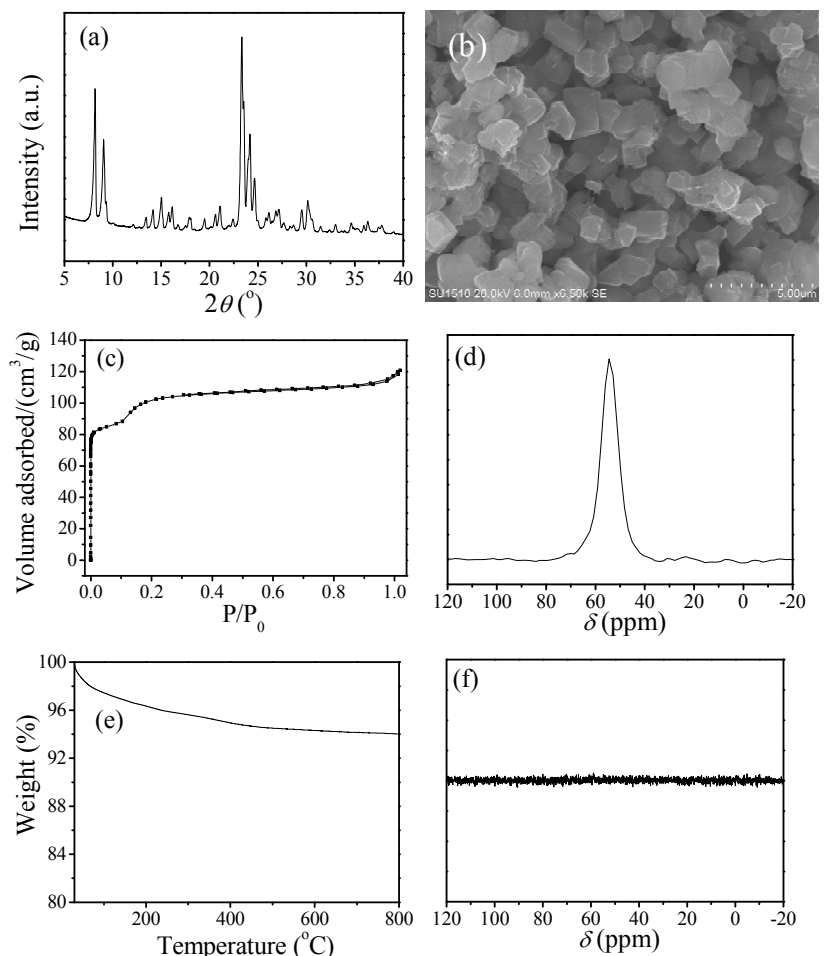

Fig. 2. XRD pattern (a), SEM image (b), $\mathrm{N}_{2}$ sorption isotherms (c), ${ }^{27} \mathrm{Al}$ MAS NMR spectrum (d), TG curve (e), and ${ }^{13} \mathrm{C}$ MAS NMR spectrum (f) of the aluminosilicate ZSM-5 zeolite sample.

TF-Al-ZSM-5-80. The XRD pattern (Fig. 2(a)) of the sample shows the well-resolved peaks associated with MFI-type zeolites [23]. The SEM image (Fig. 2(b)) of the sample shows crystals with blocky morphology. Nitrogen sorption isotherms (Fig. 2(c)) of the sample show a steep increase at the relative pressure $\left(10^{-6}<P / P_{0}<0.01\right)$, a typical feature indicating the nitrogen filling the zeolite micropores. Correspondingly, the BET surface area and micropore volume of the sample are 382 $\mathrm{m}^{2} / \mathrm{g}$ and $0.16 \mathrm{~cm}^{3} / \mathrm{g}$, respectively, which are comparable to those of ZSM-5 synthesized from the conventional route in the presence of OSDAs [36].

Figure 2(d) shows the ${ }^{27} \mathrm{Al}$ MAS NMR spectrum of the TF-Al-ZSM-5-80 zeolite. Notably, there is only one peak with the chemical shift at approximately $54 \mathrm{ppm}$ assigned to the existence of a 4-coordinated aluminum species, indicating that all aluminum species existed in the zeolite framework. Figure 2(e) shows the TG curve of the TF-Al-ZSM-5-80 zeolite which showed a weight loss of $2.4 \%$ in the temperature range of $200-800^{\circ} \mathrm{C}$. This result is reasonably attributed to dehydration rather than the loss of ethanol, as confirmed by the ${ }^{13} \mathrm{C}$ MAS NMR spectrum (Fig. 2(f)). In the ${ }^{13} \mathrm{C}$ MAS NMR spectrum, there is indeed no signal related to ethanol, indicating that ethanol was only a zeolite micropore filler [35].

It was found that many factors, such as the $\mathrm{Na}_{2} \mathrm{O} / \mathrm{SiO}_{2}$, $\mathrm{C}_{2} \mathrm{H}_{5} \mathrm{OH} / \mathrm{SiO}_{2}$, seeds $/ \mathrm{SiO}_{2}, \mathrm{H}_{2} \mathrm{O} / \mathrm{SiO}_{2}$, and $\mathrm{Si} / \mathrm{Al}$ ratios of the initial mixture, strongly influenced the synthesis of TF-Al-ZSM-5, as shown in Figs. S1-S4 and Table S1. Particularly, when Si/Al ratios of the aluminosilicate precursor in the starting mixture were adjusted from 38 to 240 , TF-Al-ZSM- 5 zeolite products 
Table 1

The Si/Al ratios of the aluminosilicate precursors and zeolite.

\begin{tabular}{lcc}
\hline Run $^{\text {a }}$ & $\mathrm{Si} / \mathrm{Al}$ ratios of precursors & $\mathrm{Si} / \mathrm{Al}$ ratios of products \\
\hline 1 & 38 & 35 \\
2 & 60 & 60 \\
3 & 80 & 80 \\
4 & 191 & 180 \\
5 & 240 & 230 \\
\hline a & &
\end{tabular}

${ }^{a}$ Crystallized at $180{ }^{\circ} \mathrm{C}$ for $48 \mathrm{~h}, \mathrm{C}_{2} \mathrm{H}_{5} \mathrm{OH} / \mathrm{SiO}_{2}=1.5$, seeds $/ \mathrm{SiO}_{2}=0.1$.

b The $\mathrm{Si} / \mathrm{Al}$ ratios were measured using inductively coupled plasma (ICP) with a Perkin-Elmer 3300DV emission spectrometer.

with $\mathrm{Si} / \mathrm{Al}$ ratios ranging from 35 to 230 were obtained (Figs. S5 and S6 and Table 1).

It is worth emphasizing the importance of the aluminosilicate precursor with a 4-coordinated $\mathrm{Al}$ species in the synthesis of TF-Al-ZSM-5 zeolites. When a mixture of conventional silica and the aluminum source was used as the starting material, the zeolite product had good crystallinity, as shown in the XRD pattern (Fig. S7). However, the zeolite product had a strong signal with a chemical shift at approximately zero ppm which relates to extra-framework aluminum species (Fig. S8). These results suggest that this product was not an aluminosilicate zeolite. However, when the aluminosilicate precursor with a 4-coordinated $\mathrm{Al}$ species was employed, a zeolite product with both high crystallinity and 4-coordinated Al species was obtained (Figs. 2(a) and 2(d)). Figure S9 presents the ${ }^{27} \mathrm{Al}$ MAS NMR spectra of the aluminosilicate precursor and the mixture of conventional silica and the aluminum source. The aluminosilicate precursor gave fully 4-coordinated Al species (Fig. S9(1)), while the mixture of conventional silica and the aluminum source had a majority of 6-coordinated Al species (Fig. S9(2)). Possibly, the 4-coordinated aluminum species in the starting materials would be an important component for successful crystallization of TF-Al-ZSM-5 zeolites.

To understand the organotemplate-free synthesis, the crystallization of the TF-Al-ZSM-5-80 zeolite was monitored via XRD, SEM, and ${ }^{27} \mathrm{Al}$ and ${ }^{29} \mathrm{Si}$ MAS NMR techniques (Fig. 3 and Fig. S10). The XRD peaks indicate that the sample was always amorphous before the crystallization, with the exception of the peaks associated with zeolite seeds (Fig. 3(a)-(1)). The XRD peak intensity of the sample that had a crystallization time of 6 $\mathrm{h}$ is relatively higher (Fig. 3(a)-(2)). For the samples taken at such time, zeolite crystals could be clearly observed in the corresponding SEM image (Fig. S10-(b)). Upon further increasing the crystallization time from 12 to $36 \mathrm{~h}$, the XRD intensity of the sample gradually increases (Fig. 3(a)-(3)-(6)). Correspondingly, more zeolite crystals could be observed in the SEM images (Fig. S10-(c)-(e)). When the crystallization reached $48 \mathrm{~h}$, the zeolite product had high crystallinity (Fig. 3(a)-(7) and Fig. S10(f)). The dependence of the product crystallinity on crystallization time is shown in Fig. S11. As observed in the ${ }^{27} \mathrm{Al}$ MAS NMR spectra, it was found that the samples always gave sharp signals centered at approximately 54 ppm (Fig. 3(b)) during the crystallization, which suggests that the aluminum species are always 4-coordinated during the synthesis. In contrast, the ${ }^{29} \mathrm{Si}$ MAS NMR spectra of the samples crystallized from 0 to $48 \mathrm{~h}$ exhibit changes in the silica species (Fig. 3(c)). For example, before crystallization, the sample exhibits signals at -116.7 , $-114.4,-110.9$, and -101.5 ppm (Table S2). The former three signals are associated with the $\mathrm{Si}(4 \mathrm{Si}, 0 \mathrm{Al})$ species, and the latter signal is mainly related to $\mathrm{Si}(3 \mathrm{Si}, 1 \mathrm{Al})$. Increasing the crystallization time led to a significant reduction of $\mathrm{Si}(3 \mathrm{Si}, 1 \mathrm{Al})$ species which transformed into $\mathrm{Si}(4 \mathrm{Si}, 0 \mathrm{Al})$ species (Table S3). These results suggest that rearrangement and condensation of the silicate species, rather than the aluminum species, occurred and the 4-coordinated $\mathrm{Al}$ species remained throughout the crystallization of the TF-Al-ZSM-5-80 zeolite. Because the $\mathrm{Si}(4 \mathrm{Si}, 0 \mathrm{Al})$ species are dominant during the crystallization, it is suggested that the rearrangement and condensation of silica species only partially occurred during the organotemplate-free synthesis of high-silica zeolites. This phenomenon is quite distinguishable from the hydrothermal synthesis of zeolites, wherein rearrangement and condensation occur for almost all silica species. Figure $\mathrm{S} 12$ shows the Si $2 p$ and Al $2 p$ XPS spectra of the TF-Al-ZSM-5-80 zeolite indicating a $\mathrm{Si} / \mathrm{Al}$ ratio of approximately 73 , which is in good agreement with the result of the ICP analysis (Si/Al ratio of approximately 80 ). This result indicates that the distribution of $\mathrm{Al}$ species in the zeolite product is uniform rather than silica-rich on the surface of the zeolite product.

Figure S13 shows the $\mathrm{NH}_{3}$-TPD curves of the TF-Al-ZSM-5 and C-Al-ZSM-5 zeolites. The $\mathrm{NH}_{3}$-TPD curve of the TF-Al-ZSM-5 zeolite shows two peaks centered at approxi-
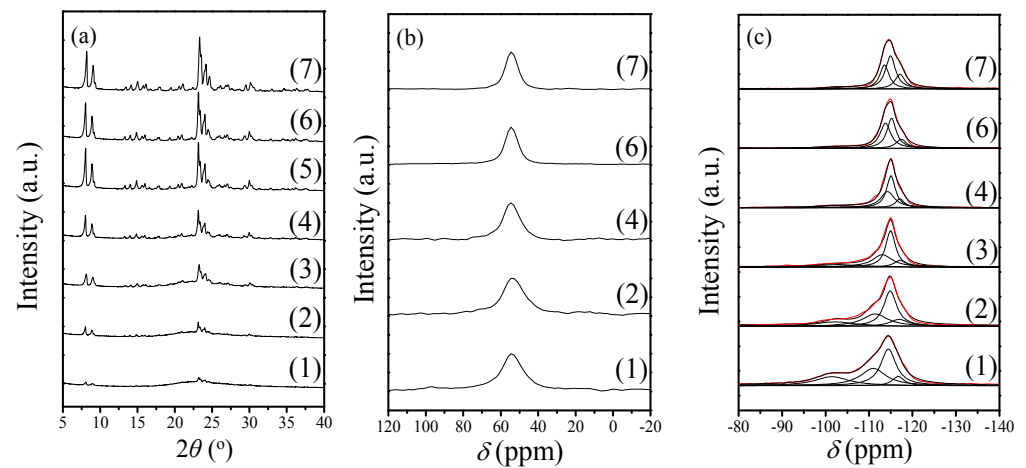

Fig. 3. XRD patterns (a), ${ }^{27} \mathrm{Al}$ MAS NMR spectra (b), and ${ }^{29} \mathrm{Si} \mathrm{MAS} \mathrm{NMR} \mathrm{spectra} \mathrm{(c)} \mathrm{of} \mathrm{the} \mathrm{TF-Al-ZSM-5-80} \mathrm{zeolite} \mathrm{crystallized} \mathrm{at} 0$ (1), 6 (2), 12 (3), 18 (4), 24 (5), 36 (6), and $48 \mathrm{~h}(7)$. In Fig. 3(c), the red line is the original peak, and the black lines are the deconvoluted peaks. The original peak was deconvolved into several peaks using the Lorenz decomposition fitting model. 


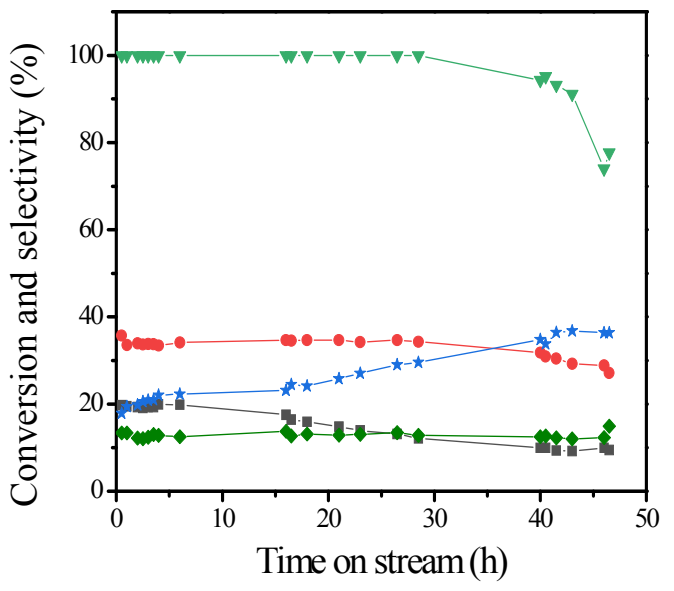

Fig. 4. Methanol conversion and product selectivities over the aluminosilicate TF-ZSM-5 zeolite with a Si/Al ratio of 80 in the product at 480 ${ }^{\circ} \mathrm{C}\left(\boldsymbol{\nabla}\right.$, Conv.; $\left.\mathbf{m}, \mathrm{C}^{2=} ; \bullet, \mathrm{C}^{3=} ; \bullet, \mathrm{C}^{4=} ; \star, \mathrm{C}^{5+}\right)$.

mately 190 and $393{ }^{\circ} \mathrm{C}$, which are lower than that of C-Al-ZSM-5 zeolites. In addition, the concentration of acidic sites over the TF-Al-ZSM-5 zeolite is notably lower than that of C-Al-ZSM-5 zeolites. The above phenomenon might be caused by different $\mathrm{Al}$ distributions in the zeolite products; further work regarding this phenomenon is still under investigation. Figure 4 shows the catalytic performance during the MTP reaction over the TF-Al-ZSM-5-80 zeolite with a size of 1-2 $\mu \mathrm{m}$, as a function of reaction time at $480{ }^{\circ} \mathrm{C}$. The catalytic performance of the TF-Al-ZSM-5-80 zeolite was completely comparable to that of a similarly sized aluminosilicate ZSM-5 zeolite synthesized in the presence of OSDAs (Figs. S14 and S15). Both zeolite catalysts had similar activities, selectivities, and catalyst lifetimes.

After the successful synthesis of TF-Al-ZSM- 5 zeolites, the synthesis was extended to incorporate heteroatoms such as Fe and $B$ into the framework of the MFI structure. Figure 5(a) shows XRD patterns of TF-Fe-ZSM- 5 and TF-B-ZSM- 5 zeolites exhibiting significantly good crystallinity. The SEM images of

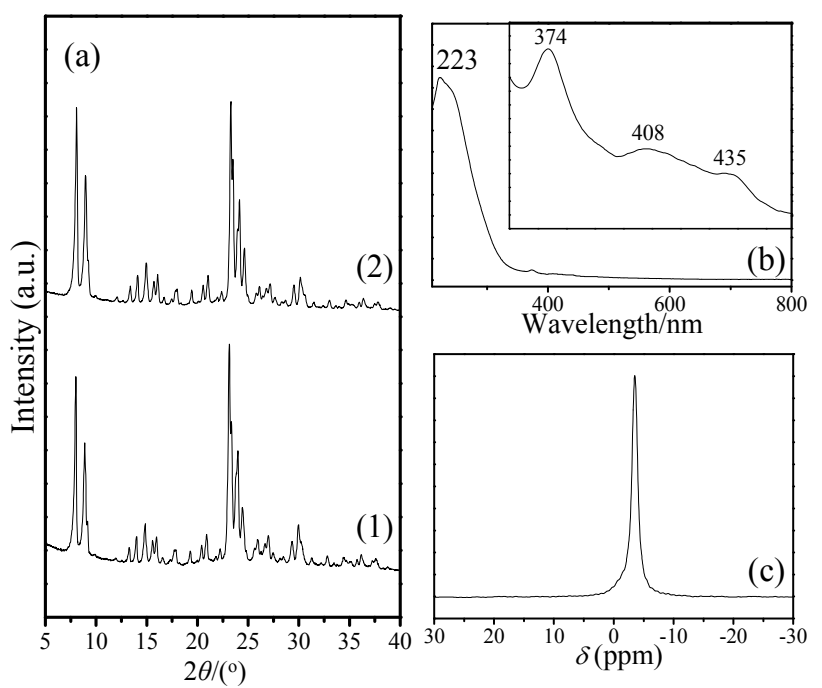

Fig. 5. (a) XRD patterns of TF-Fe-ZSM-5 (1) and TF-B-ZSM-5 (2) zeolites (b) UV-Vis spectrum of TF-Fe-ZSM-5 zeolite; (c) ${ }^{11 B}$ MAS NMR spectrum of TF-B-ZSM-5 zeolite.

the aforementioned samples (Fig. S16) show typical MFI morphology. The $\mathrm{Fe}$ and $\mathrm{B}$ heteroatoms existed in the zeolite framework, as supported by the UV-Visible and MAS NMR spectra. The UV-Vis spectrum of the TF-Fe-ZSM-5 zeolite (Fig. 5(b)) had bands at 223, 374, 408, and $435 \mathrm{~nm}$, which are consistent with those of tetrahedral environments of $\mathrm{Fe}^{3+}$ species in the zeolite framework $[37,38]$. The 11B MAS NMR spectrum of the TF-B-ZSM-5 zeolite (Fig. 5(c)) shows a peak at -3.49 ppm, which is associated with $\mathrm{B}(\mathrm{SiO})_{4}$ units in the zeolite framework $[39,40]$. ICP analysis shows that the Si/Fe ratio in the TF-Fe-ZSM-5 zeolite and the Si/B ratio in the TF-B-ZSM-5 zeolite were approximately 100 and 71, respectively.

In addition to the organotemplate-free synthesis of high-silica MFI zeolites, we also performed the organotemplate-free synthesis of other high-silica zeolites, including TON, MTT, and *MRE structures. Figure 6 shows the XRD patterns, SEM images, and ${ }^{27} \mathrm{Al}$ MAS NMR spectra of TF-Al-ZSM-22,
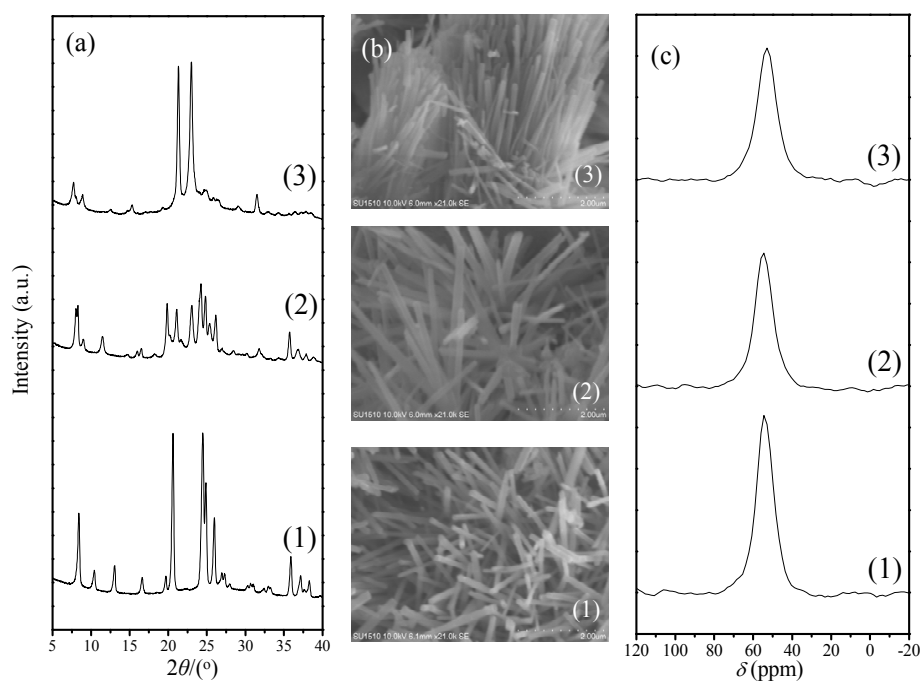

Fig. 6. XRD patterns (a), SEM images (b), and ${ }^{27} \mathrm{Al}$ MAS NMR spectra (c) of TF-Al-TON (1), TF-Al-MTT (2), and TF-Al-*MRE (3) zeolites. 
TF-Al-ZSM-23, and TF-Al-ZSM-48 zeolites. The XRD patterns of these samples indicate pure zeolite phases with good crystallinities (Fig. 6(a)) [41-43]; the SEM images of the samples show typical rod-like crystals (Fig. 6(b)); the ${ }^{27} \mathrm{Al}$ MAS NMR spectra of the samples display peaks at 54 ppm (Fig. 6(c)), which is assigned to a 4-coordinated aluminum species in the zeolite framework. ICP analyses show that the $\mathrm{Si} / \mathrm{Al}$ ratios of the aluminosilicate TF-ZSM-22, TF-ZSM-23, and TF-ZSM-48 zeolites were 45,47 , and 66 , respectively. These results suggest that the organotemplate-free synthesis of high-silica zeolites in this work is a plausible generalized scheme, and more examples are under investigation to validate these observations.

\section{Conclusions}

In summary, the organotemplate-free synthesis of high-silica zeolites with MFI, TON, MTT, and *MRE structures using aluminosilicate precursors as the starting source in the presence of zeolite seeds and ethanol was successful. As a typical example, when the aluminosilicate precursors were employed, a high-silica ZSM-5 zeolite (TF-Al-ZSM-5) was synthesized in the absence of any organic template. Characterizations of the TF-Al-ZSM-5-80 crystallization revealed that the rearrangement and condensation of the silicate species partially occurred, and the 4-coordinated $\mathrm{Al}$ species remained in both the amorphous phase and zeolite crystals. Catalytic tests for the
MTP reaction showed that the TF-Al-ZSM-5-80 was considerably active and selective, which is fully comparable to those of the aluminosilicate ZSM-5 zeolites synthesized in the presence of organic templates. When borosilicate and ferrosilicate were used, TF-B-ZSM-5 and TF-Fe-ZSM-5 zeolites, respectively, were successfully obtained in the absence of organic templates, which suggests that the organotemplate-free method is viable as a generalized route for the synthesis of high-silica zeolites. Compared with the conventional hydrothermal route, this work has obvious advantages as follows: (1) avoidance of costly and toxic OSDAs; (2) reduction of polluted water; (3) simplification of the synthetic process; and (4) high zeolite product yield (approximately 93\%). It is expected that these advantages, in addition to excellent catalytic performance, might offer good opportunities for the industrial production and catalytic application of high-silica zeolites in the future.

\section{References}

[1] J. Shin, D. Jo, S. B. Hong, Acc. Chem. Res., 2019, 52, 1419-1427.

[2] F. D. Liu, Y. B. Yu, H. He, Chem. Commun., 2014, 50, 8445-8463.

[3] S. Y. Li, J. F. Li, M. Dong, S. B. Fan, T. S. Zhao, J. G. Wang, W. B. Fan, Chem. Soc. Rev., 2019, 48, 885-907.

[4] M. Dusselier, M. E. Davis, Chem. Rev., 2018, 118, 5265-5329.

[5] P. Tian, Y. X. Wei, M. Ye, Z. M. Liu, ACS Catal., 2015, 5, 1922-1938.

[6] C. G. Li, M. Moliner, A. Corma, Angew. Chem. Int. Ed., 2018, 57, 15330-15353.

\section{Graphical Abstract}

Chin. J. Catal., 2021, 42: 563-570 doi: 10.1016/S1872-2067(20)63677-4

\section{Alcohol-assisted synthesis of high-silica zeolites in the absence of organic structure-directing agents}

Huimin Luan, Chi Lei, Ye Ma, Qinming Wu*, Longfeng Zhu, Hao Xu, Shichao Han, Qiuyan Zhu, Xiaolong Liu*, Xiangju Meng, Feng-Shou Xiao *

Zhejiang University; Jiaxing University; Sun Yat-Sen University

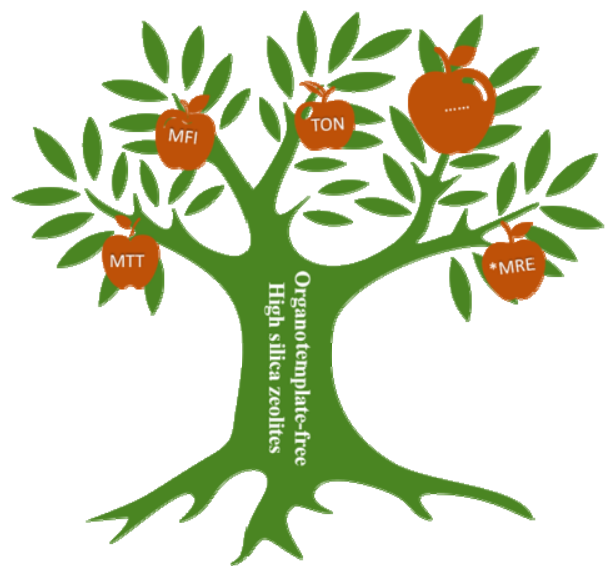

High-silica zeolites with MFI, TON, MTT, and *MRE structures were successfully synthesized using aluminosilicate precursors as the starting sources in the presence of alcohol and zeolite seeds, where the alcohol and seeds were critical for filling and directing, respectively. 
[7] V. Valtchev, L. Tosheva, Chem. Rev., 2013, 113, 6734-6760.

[8] E. P. Ng, D. Chateigner, T. Bein, V. Valtchev, S. Mintova, Science, 2012, 335, 70-73.

[9] M. Choi, K. Na, J. Kim, Y. Sakamoto, O. Terasaki, R. Ryoo, Nature, 2009, 461, 246-249.

[10] X. Y. Zhang, D. X. Liu, D. D. Xu, S. Asahina, K. A. Cychosz, K. V. Agrawal, Y. Al Wahedi, A. Bhan, S. Al Hashimi, O. Terasaki, M. Thommes, M. Tsapatsis, Science, 2012, 336, 1684-1687.

[11] V. Vattipalli, A. Paracha, W. Hu, H. Chen, W. Fan, Angew. Chem. Int. Ed., 2018, 57, 3607-3611.

[12] R. Li, N. Linares, J. G. Sutjianto, A. Chawla, J. Garcia-Martinez, J. D. Rimer, Angew. Chem. Int. Ed., 2018, 57, 11283-11288.

[13] Z. D. Liu, T. Wakihara, K. Oshima, D. Nishioka, Y. Hotta, S. P. Elangovan, Y. Yanaba, T. Yoshikawa, W. Chaikittisilp, T. Matsuo, T. Takewaki, T. Okubo, Angew. Chem. Int. Ed., 2015, 54, 5683-5687.

[14] D. W. He, D. H. Yuan, Z. J. Song, Y. Xu, Z. Liu, Chin. J. Catal., 2019, 40, 52-59.

[15] Q. M. Sun, N. Wang, R. S. Bai, X. X. Chen, J. H. Yu, J. Mater. Chem. A, 2016, 4, 14978-14982.

[16] D. Jo, J. B. Lim, T. Ryu, I. S. Nam, M. A. Camblor, S. B. Hong, J. Mater. Chem. A, 2015, 3, 19322-19329.

[17] D. W. Fickel, E. D’Addio, J. A. Lauterbach, R. F. Lobo, Appl. Catal. B, 2011, 102, 441-448.

[18] D. Xie, L. B. McCusker, C. Baerlocher, S. I. Zones, W. Wan, X. Zou, J. Am. Chem. Soc., 2013, 135, 10519-10524.

[19] B. T. Yang, J.-G. Jiang, H. Xu, H. H. Wu, M. Y. He, P. Wu, Angew. Chem. Int. Ed., 2018, 57, 9515-9519.

[20] Q. M. Wu, X. J. Meng, X. H. Gao, F.-S. Xiao, Acc. Chem. Res., 2018, 51, 1396-1403.

[21] A. Rojas, E. Martinez-Morales, C. M. Zicovich-Wilson, M. A. Camblor, J. Am. Chem. Soc., 2012, 134, 2255-2263.

[22] Q. Zhang, G. R. Chen, Y. Y. Wang, M. Y. Chen, G. Q. Guo, J. Shi, J. Luo, J. H. Yu, Chem. Mater., 2018, 30, 2750-2758.

[23] X. B. Zhao, H. Yang, L. Y. Wang, D. Fan, N. N. Yan, X. N. Liu, P. Tian, X. W. Guo, Z. M. Liu, Chin. J. Catal., 2018, 39, 1418-1426.

[24] G. L. Zhao, J. W. Teng, Q. Y. Song, Z. Xie, Q. Chen, Chin. J. Catal., 2003, 24, 119-122.

[25] C. S. Mei, P. Y. Wen, Z. C. Liu, H. X. Liu, Y. D. Wang, W. M. Yang, Z.
Xie, W. Hua, Z. Gao, J. Catal., 2008, 258, 243-249.

[26] M. Zhang, Y. J. Chen, L. Wang, Q. M. Zhang, C. W. Tsang, C. H. Liang, Ind. Eng. Chem. Res., 2016, 55, 6069-6078.

[27] H. R. Li, C. L. Liu, Y. Wang, J. J. Zheng, B. B. Fan, R. F. Li, RSC Adv., 2018, 8, 28909-28917.

[28] J. W. Song, L. Dai, Y. Y. Ji, F.-S. Xiao, Chem. Mater., 2006, 18, 2775-2777.

[29] Z. F. Wu, J. W. Song, Y. Y. Ji, L. M. Ren, F.-S. Xiao, Chem. Mater., 2008, 20, 357-359.

[30] B. Xie, J. W. Song, L. M. Ren, Y. Y. Ji, J. X. Li, F.-S. Xiao, Chem. Mater., 2008, 20, 4533-4535.

[31] G. Majano, L. Delmotte, V. Valtchev, S. Minova, Chem. Mater., 2009, 21, 4184-4191.

[32] X. L. Huang, Z. B. Wang, Chin. J. Catal., 2011, 32, 1702-1711.

[33] Y. Kubota, K. Itabashi, S. Inagaki, Y. Nishita, R. Komatsu, Y. Tsuboi, S. Shinoda, T. Okubo, Chem. Mater., 2014, 26, 1250-1259.

[34] Q. M. Wu, X. Wang, X. J. Meng, C. G. Yang, Y. Liu, Y. Y. Jin, Q. Yang, F.-S. Xiao, Microporous Mesoporous Mater., 2014, 186, 106-112.

[35] Q. M. Wu, L. F. Zhu, Y. Y. Chu, X. L. Liu, C. S. Zhang, J. Zhang, H. Xu, J. Xu, F. Deng, Z. C. Feng, X. J. Meng, F.-S. Xiao, Angew. Chem. Int. Ed., 2019, 58, 12138-12142.

[36] L. M. Ren, Q. M. Wu, C. G. Yang, L. F. Zhu, C. Li, P. L. Zhang, H. Y. Zhang, X. J. Meng, F.-S. Xiao, J. Am. Chem. Soc., 2012, 134, 15173-15176.

[37] D. D. Guo, B. J. Shen, G. D. Qi, L. Zhao, J. Xu, F. Deng, Y. C. Qin, Q. X. Guo, S. Y. Ren, X. H. Gao, S. Qin, B. J. Wang, H. J. Zhao, H. H. Liu, X. M. Pang, Chem. Commun., 2014, 50, 2660-2663.

[38] E. J. M. Hensen, Q. Zhu, R. A. J. Janssen, P. C. M. M. Magusin, P. J. Kooyman, R. A. van Santen, J. Catal., 2005, 233, 123-135.

[39] L. Chen, M. J. Zhang, Y. Yue, C. H. Ye, F. Deng, Microporous Mesoporous Mater., 2004, 76, 151-156.

[40] T. Yokoi, M. Yoshioka, H. Imai, T. Tatsumi, Angew. Chem. Int. Ed., 2009, 48, 9884-9887.

[41] Q. Wang, Z. M. Cui, C. Y. Cao, W. G. Song, J. Phys. Chem. C, 2011, 115, 24987-24992.

[42] Q. M. Wu, X. Hong, L. F. Zhu, X. J. Meng, S. C. Han, J. Zhang, X. L. Liu, C. H. Jin, F.-S. Xiao, Microporous Mesoporous Mater., 2019, 286, 163-168.

[43] Y. J. Zhang, Y. H. Ma, S. A. Che, Chem. Mater., 2018, 30, 1839-1843.

\title{
在无有机导向剂条件下采用乙醇为助剂合成高硅沸石
}

\author{
奕慧敏 ${ }^{\mathrm{a}}$, 雷 驰 ${ }^{\mathrm{a}}$, 马 野, 吴勤明 ${ }^{\mathrm{a}}{ }^{*}$, 朱龙凤 ${ }^{\mathrm{b}}$, 徐 好 ${ }^{\mathrm{a}}$, 韩世超 ${ }^{\mathrm{a}}$, 朱秋艳 ${ }^{\mathrm{a}}$, 刘小龙, 井, \\ 孟祥举 ${ }^{a}$, 肖丰收 ${ }^{a, \$}$ \\ a浙江大学化学系, 浙江省应用化学重点实验室, 浙江杭州 310028 \\ $\mathrm{b}$ 嘉兴学院生物与化学工程学院, 浙江嘉兴 314001 \\ c中山大学材料学院, 广东广州510006
}

摘要: 高硅沸石具有优异的热稳定性、水热稳定性、大的微孔体积、高表面积和均匀的微孔孔道, 因而广泛应用于催化领 域. 然而, 高硅沸石的合成往往需要使用有机结构导向剂, 不但增加了沸石合成成本, 而且还产生了大量的三废排放. 为了 解决这个问题, 我们发展了在无有机导向剂存在条件下采用沸石晶种诱导合成沸石的方法, 但是该方法合成的沸石产物骨 架富铝, 不能合成高硅沸石, 实现绿色方法合成工业上大量使用的高硅沸石问题仍然没有解决. 最近, 我们又报道了采用 沸石晶种导向和醇填充相结合的方法合成纯硅沸石, 但仍不能合成高硅沸石.

本文首次在无有机结构导向剂存在条件下采用乙醇为助剂合成高硅沸石, 并成功地合成了硅铝比(Si/Al)为38-240的 ZSM-5沸石. 此方法成功的关键是使用具有四配位铝物种的硅铝酸盐前驱体作为起始原料. 因为乙醇的沸点低, 溶液中的 乙醇可以循环使用, 大幅度地降低了传统高硅沸石合成有机模板的三废排放成本. 通过固体核磁证明, 在沸石的晶化过程 中, 硅物种发生重排与聚合, 而铝物种一直保持着四配位的状态不变, 这表明 Si-O-Al类的连接在晶化过程中基本上保持稳 
定. 另外, 采用该方法合成了高硅TON, MTT, ${ }^{*} \mathrm{MRE}$ 沸石, 表明了此方法的普适性. 此外, 还可以将Fe和 $\mathrm{B}$ 等杂原子引入到 沸石骨架中, 成功地合成了铁硅和硼硅沸石.

$X$ 射线粉末衍射测试与扫描电子显微镜表征结果表明, 所合成的高硅ZSM-5沸石具有高纯度和结晶度, 样品呈现出典 型的块状ZSM-5 晶体形貌. 样品的BET表面积和微孔体积分别为 $382 \mathrm{~m}^{2} / \mathrm{g}$ 和 $0.16 \mathrm{~cm}^{3} / \mathrm{g}$, 这与传统方法以TPAOH为有机结 构导向剂合成的ZSM-5沸石的BET表面积和微孔体积是几乎一致的. 更重要的是, 所制备的ZSM-5沸石在甲醇制丙烯反应 中, 具有良好的催化性能, 并与使用有机结构导向剂合成的ZSM-5沸石具有相似的活性、选择性和催化剂寿命.

综上所述, 在沸石晶种和乙醇存在的条件下, 以硅铝酸盐前驱体为起始原料, 在无有机结构导向剂存在条件下, 成功地 合成出了高硅MFI, TON, MTT和*MRE沸石. 同时, 也可利用嗍硅酸盐和铁硅酸盐为起始原料来合成B-ZSM-5 和Fe-ZSM-5 沸石. 与传统的合成高硅沸石路线相比, 此方法避免了昂贵和有毒的有机结构导向剂的使用、减少了废水的排放、简化了 合成过程和提高了产品收率; 同时所合成沸石具有优异的催化性能, 为高硅沸石的产业化生产和催化应用奠定基础. 关键词: 沸石; 高硅; 晶种导向; 醇填充; 催化性能

收稿日期: 2020-05-08. 接受日期: 2020-06-25. 上网日期: 2020-09-05.

*通讯联系人. 电话/传真: (0571)8273698; 电子信箱: qinmingwu@zju.edu.cn

\#通讯联系人. 电话/传真: (020)83642214; 电子信箱: liuxlong9@mail.sysu.edu.cn

\$通讯联系人. 电话/传真: (0571)8273698; 电子信箱: fsxiao@zju.edu.cn

基金来源: 国家重点研究发展计划(2017YFB0702803); 国家自然科学基金(21720102001, 91634201, 21703203, 21802053).

本文的电子版全文由Elsevier出版社在ScienceDirect上出版(http://www.sciencedirect.com/science/journal/18722067). 